\title{
TRADE RESTRICTIONS HAMPER WORLD TRADE GROWTH
}

\author{
N. Volovik
}

World trade growth rates have significantly slowed: in 2015, the volume of world trade went up by $2.8 \%$ and according to the WTO forecast will remain at the same level throughout 2016. As a result, the current year will be the fifth year in a row when the trade turnover will increase by less than 3\%. Furthermore, during the period from 1990 through 2008 the average indicator remained at the level of $5 \%$.

In Q1 2016, indicators of the international merchandise trade for G-20 member states continued falling and hit six-year lows. According to the OECD quarterly report for January-March 2016 ${ }^{1}$, G-20 merchandise exports expressed in dollars and seasonally adjusted contracted for the seventh consecutive drop, imports for the eighths consecutive drop (by $3.8 \%$ and $4.1 \%$, respectively). For example, if in Q1 2015, G-20 merchandise exports constituted $\$ 3,243.2 \mathrm{bn}$ and imports - \$3,214.0bn, then in Q4 2015 these indicators contracted to $\$ 3,099.6 \mathrm{bn}$ and $\$ 3,090.4 \mathrm{bn}$, and in Q1 2016 - down to $\$ 2,983.0 \mathrm{bn}$ and $\$ 2,954.4 \mathrm{bn}$.

The world trade growth rates slowdown is affected by many factors including non-tariff measures applied by many countries. According to the $15^{\text {th }}$ WTO trade monitoring report on G-20 trade measures ${ }^{2}$, in the period from mid-October 2015 through mid-May 2016 G-20 economies applied 145 new trade-restrictive measures, or an average of almost 21 new measures a month. This is the highest average monthly indicator registered since the WTO began its monitoring exercise in 2009. To note, in 2009 this indictor hit 19, in $2010-14$, in $2011-18$, in 2012 - 17, in 2013-2015 - 18 each, and in October 2014 - May 2015, and May-October 2015 - 17 new measures each.

Total number of trade-restrictive measures continues growing: of the 1,583 trade-restrictive measures recorded for G-20 economies since 2008 by this monitoring exercise, only 387 had been removed. Thus, the total number of restrictive measures still in place now stands at 1,196 , which is by 109 measures more compared to the data released in the previous WTO report.

According to the WTO, the highest share in the total number of applied non-tariff measures falls on sanitary and phytosanitary measures $(28.4 \%$ of the total non-tariff measures). Technical barriers to trade follow next (19.5\%) and anti-dumping measures (14.1\%) (Fig. 1).

According to the WTO Agreement on application of sanitary and phytosanitary measures (SPS) each WTO member has the right to apply measures aimed at food security, animal and plant health, but must in advance inform about the new or changing SPS measures, envisaging reasonable timeline between the publication of any sanitary or phytosanitary rule and its coming

1 http://www.oecd.org/newsroom/international-trade-statistics-trends-in-first-quarter-2016.htm

2 https://www.wto.org/english/news_e/news16_e/trdev_21jun16_e.htm 
into effect. In exceptional cases, the notification must be released immediately following the imposition of measures. The notification system allows wherever necessary carry out consultations at the international level by commenting planned measures and receiving necessary clarifications.

The total number of SPS notifications is steadily growing hitting in 2015 its all-time high - 1,681 notifications (year earlier $-1,633$ notifications). Of which 1,166 were regular notifications (in $2014-1,057$ ), and 401 were additions or corrections to previously filed notifications, and 114 were urgent notifications.

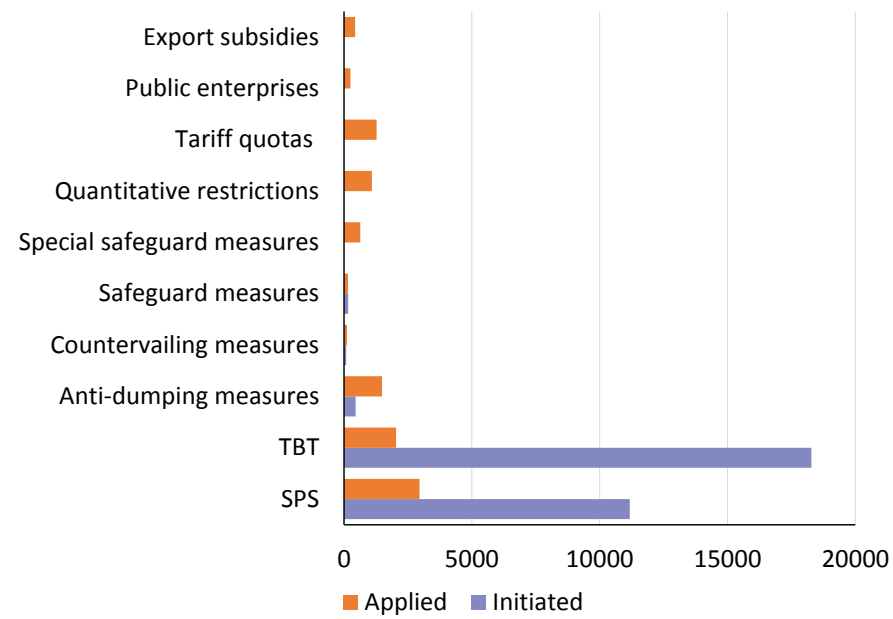

Source: WTO official site: http://i-tip.wto.org/goods/Forms/ GraphView.aspx

Fig. 1. Number of imposed and still in place nontariff measures (as of 31 December 2015)

The WTO Agreement on technical

barriers to trade acknowledges the right of the countries to adopt measures necessary for securing the quality of their exports or protection of life and health of people, animal and plant health, protection of environment at the level, which they consider appropriate. However, these measures should not be instrumental for arbitral and unjustified discrimination between the countries or for covert restrictions of world trade.

According to the $27^{\text {th }}$ annual review on the implementation of the Agreement on technical barriers to trade (TBT), in 2015 the WTO members filed to the Committee on technical barriers to trade a total of 1,988 notifications, which was by $12 \%$ less than in 2014.1438 notifications about the new technical regulations and procedures on compliance assessment were filed. Moreover, 27 changes, 476 additions, and 47 corrections were filed. From the effective date of the WTO Agreement on TBT through 31 December 2015, 128 WTO members filed notifications totaling 25,390.

Leaders among the WTO members are the USA - 2,459 TBT notifications, Brazil $-1,325$ notifications, the EU $-1,253$ notifications, and China 1,237 notifications.

Imposition of anti-dumping duties represent a rather widespread measure to protect the domestic market. During the WTO life-time, i.e. since 1995, India is the leader in the initiation of anti-dumping measures by submitting 767 claims, which constitutes $15 \%$ of the overall number of filed claims $(4,990)$. The USA over this period conducted 570 anti-dumping cases, meanwhile the EU - 480. At the same time, not all cases resulted in the application of anti-dumping duties. India imposed 534 anti-dumping measures, the USA - 345, and the EU - 298.

In 2015, the United States overtook India by initiating 43 anti-dumping cases and 22 probes into illegal subsidizing of exports. The EU during 2015 initiated 12 cases against unfair trade.

Major share of antidumping disputes fall on metal products, especially on steel products. Steel glut on world markets, sharp drop of prices on this product, significant changes in trade flows, and contraction of labor market and growth of the safeguard measures - all these factors trigger escalation of ten- 
sions in the relations between countries. As a result, out of 233 anti-dumping disputes filed all over the world in 2015108 were linked to the supplies of steel products at knock-down prices. Most often disputes are filed against the supplies of steel products from the People's Republic of China. According to the American and European metallurgists, the PRC authorities provide illegal support to the sector, owing to which the Chinese iron and steel plants obtain possibility to sell their products at prices below cost.

According to the data released by the Ministry of Economic Development, as of 1 May 2016, in relation to Russian products are in place 123 trade restrictive measures including: anti-dumping duties -43 , special safeguard duties -16 , countervailing duties -1 , other non-tariff measures 63 (out of which administrative measures including additional levies and restrictions on nomenclature) -25 , technical barriers -10 , tariff quotas -3 , quota restrictions -1 , excises on discriminatory basis -5 , bans on imports -4 , sanitary and phytosanitary measures -9 , risk of imposition of measures -6 ). Also, there are 17 ongoing investigations, of which 7 anti-dumping, 9 special safeguard and 1 countervailing investigation as well as 10 reviews of antidumping measures.

On 14 May 2015 the European Union initiated a dispute (notification No. 2015/C 161/07OJ) regarding certain types of cold-rolled flat products. On 10 February 2016 on the basis of Regulation EU No 2016/181 temporary measures were applied in the following amounts:

- OJSC "Severstal" - 25.4\%;

- JSC "Magnitogorsk Iron and Steel Works" (МMK) - 19.8\%;

- JSC "Novolipets Iron and Steel Works" (NLMK) - 26.2\%;

- for all other Russian companies $-26.2 \%$.

On 30 May 2016, the European Commission decided to increase antidumping duties for the Russian suppliers of cold-rolled products. The new duty constituted $34.1 \%$ for Severstal, and 36.1\% for NLMK. The duty for MMK on the contrary was reduced to $18.7 \%$. This decision was taken following the recalculation of companies' spread: if before the European Commission considered that the spread was in the range of $25.4 \%$ (Severstal) to $26.2 \%$ (NLMK), then now they understand that the spread constitutes between 63.8\% (Severstal) to $68.3 \%$ (NLMK). The European Commission must adopt the final decision in August.

The United States have also adopted preliminary anti-dumping duties on imports of cold-rolled products from China, Korea, India, Japan, Great Britain, Brazil, and Russia. Preliminary anti-dumping duty for Russian producers constituted $14.8 \%$, for Severstal $-12.6 \%$, and for NLMK $-16.89 \%$. The final decision will be taken in July 2017.

The Indian government in a bid to protect their producers has taken in recent months unprecedented steps aimed at restricting imports of steel products. India is the third largest producer of steel in the world with $89.4 \mathrm{mn}$ tons in 2015 ( $87.3 \mathrm{mn}$ in 2014). Representatives of the metallurgical industry of this country claim that they are being phased out for the domestic market by cheap imports from China, Russia, Japan, and South Korea. In order to restrict imports, India extended protective import duties imposed in 2015 to the tune of $20 \%$ on certain types of steel products through 2018. On 11 April 2016, the General Directorate on anti-dumping and associated duties of the Ministry of Trade and Industry of India initiated anti-dumping investigation 
against imports of certain types of hot-rolled products originating among others from the Russian Federation.

For the protection of their domestic market in addition to anti-dumping duties countries impose other trade barriers. For example, on 28 April 2016, the European Commission adopted a regulation, which tightened control over steel imports and would be effective through May 2020. The importers must obtain permits and submit preliminary information of shipments in order to carry out deliveries of practically all types of rolled products including pipes and metal ware. Deliveries in excess of 2.5 tons are subject to control. In declaring volumes and price a five percent margin of error is acceptable. The delivery license is valid for four months and can be extended for the same period. Requirements to importers entered into force upon 21 days after the publication of the regulation.

On 5 February 2016, the Ministry of Trade and Industry of India imposed minimum price on imports of 173 iron and steel products in the range of $\$ 341$ to $\$ 752$ per ton.

Adopted by the United States, the European Union, India, and other countries measures restricting trade hamper deliveries of the Russian metal products abroad. At the same time, it should be noted that prices set by the Russian exporters on foreign markets fell not due to dumping, they were significantly affected by the ruble's devaluation. 